\title{
Adverbs of time
}

\author{
SVend ØstergaARD \\ Center for Semiotik, Aarhus Universitet, Danmark
}

Tidsadverbierne allerede, stadig, endnu, endelig og snart markerer en afstand mellem, hvad udsigeren forventer, og hvad der faktisk er tilfældet. Hvis forventningen er en tilstands ophør eller indtræffen, har vi den tidslige "betydning". I de simple tilfælde markerer de forskellige adverbier forskellige relationer mellem udsigelsestidspunktet, tilstandens forventede forandring og dens faktiske forandring. I de mere komplekse tilfælde markerer de en konflikt mellem en tilstand og en heraf afhængig begivenhed. Adverbiernes semantik er imidlertid ikke bundet til tid, men implicerer en generel skematik, hvor en tilstand afhænger af en skala - der prototypisk kan være tiden - og hvor adverbiet implicerer en konflikt mellem udsigerens mentale repræsentation af, hvor på skalaen tilstanden er placeret, og hvor den faktisk befinder sig. Tidsadverbierne er primært udsigelsesmarkører.

\section{INTRODUCTION}

In this paper I present an analysis of some adverbs of time by applying the general methodological strategy of cognitive linguistics, especially as implemented in the work of Fauconnier (1997). This implies that the representations of time are considered as constructions available for the speaker to present the focus of the sentence from a specific temporal or epistemic viewpoint. Consider the following example from Turner (1996): a woman is going to take a bath and her husband asks "What about the mosquito netting?" If the woman now chooses to answer: "My husband took care of that while I was in the shower," the past tense is used about a future event. In this way the woman constructs a fictive viewpoint posterior to the event, presumably in order to show the high degree of expectation as to the doings of her husband. In the case of the adverbs I consider in this paper, the speaker basically wants to contrast a factual event with a counterfactual expected variant of reality in which the speaker is emotionally engaged.

Another important notion in cognitive linguistics is s che maticity. Adverbs like finally, still, and already encode in their basic meaning a specific relation between a hypothetical event, a real event and the moment of speech. We can call this relation a "schema". It might be experientially motivated, but what concerns me here is its relation to other non-temporal meanings of the adverbs. Given an adverb with, say, five different meanings, do we have five different words or do we have one word with schematically motivated extensions? 
In cognitive linguistics it is assumed that category extension goes mainly by schematic and by metonymic extensions. The latter we can identify with a shift in profile, as, for example, occurs with door, which can profile both the thing we move and the opening itself. The claim is thus that the various meanings of an adverb of time can be accounted for by schematic and metonymic extensions. Moreover, the adverbs I will consider - allerede /already, endnu /yet, stadig /still, and endelig /finally — seem to mirror each other in the sense that they make up the combinatorial possibilities of placing the moment of speech, the hypothetical event, and the factual event on a time scale.

\section{Allerede/Already}

The prototypical meaning of allerede is expressed by the following sentence: han er allerede foerdig/he has already finished. This sentence states factually that he has finished and that the finishing is prior to the moment of speaking. But allerede/already also evokes a counterfactual content that typically represents the speaker's expectation that the event would occur later than the moment of speaking. The speaker thus has two representations in mind, as shown in fig. $1 \mathrm{a}$, where $A$ marks the factual occurrence of an event, $A^{\prime}$ marks the counterfactual occurrence, and $S$ is the moment of speech. For the sake of convenience, I join the two representations in one figure, see fig. $1 \mathrm{~b}$, where the moment of speech now lies between the two events.

counterfactual space

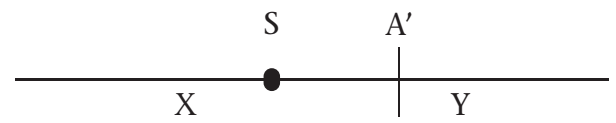

factual space

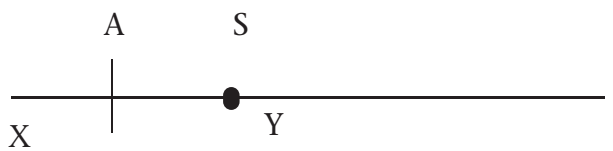

Fig. 1a

Fig. 1b

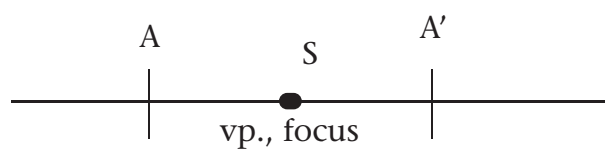

Moreover, in the first example - the English version - the focus and the viewpoint are located at $S$, since the information about $A$ is in the perfect tense and is therefore considered relevant at the moment of speech; cf. Fauconnier (1997: 80).

\subsection{TeMporal Meaning (CASE I)}

Allerede/already has in general a state as its scope, but this state must either be identical to a process that has started (at $A$ ) and will continue (han er allerede ved at blive gammel) 
he is already starting to get old) or be the result of a process that has culminated (at $A$ ) (han er allerede gammel/he is already old). Out of context Han er allerede rødhåret/he is already red haired is odd because there is no reference to a previous process causing a change of state.

$A$ therefore marks a state transition and it is the state (and not $A$ ) that is the focus of the sentence. If there is a full instantiation of the state at the moment of speech, the verb will be in the present tense (cf. Langacker 1991: 89) and we have the situation depicted in figs. 1 . The adverb allerede /already now encodes that the speaker expected $A$ to happen later than is the case.

If the state is prior to the moment of speech, then the transition $A$ cannot be unexpected because everything is in the past and known to the speaker. Concerning the use of allerede /already, this gives us two possibilities:

1 .

The focus is on another event E occurring in the time span between $A$ and $A^{\prime}$ and $A$ might be considered early relative to $\mathrm{E}$. In grammatical terms, $\mathrm{E}$ will be in the past tense, and viewpoint and focus are delegated from $S$ to the event $\mathrm{E}$. It is as if $A$ is evaluated from $\mathrm{E}$. Since the focus is on $\mathrm{E}$ and the occurrence of $A$ represents relevant information at the moment of $\mathrm{E}$, the state transition $A$ will be in the perfect tense. This is a general fact about tense structure in English and Danish; cf. again Fauconnier (1997: 80). Consider the following example: forestillingen var allerede begyndt, da de ankom til teatret/the play had already begun when they arrived at the theater. The event $\mathrm{E}$ is the arrival, which is the focus of the sentence. The state is the play and $A$ is the beginning of the play. Since $A$ is relevant for $\mathrm{E}$, it is in the perfect tense. Allerede/already encodes that the occurrence $A$ is too early relative to the event $\mathrm{E}$; cf. fig. 2 .

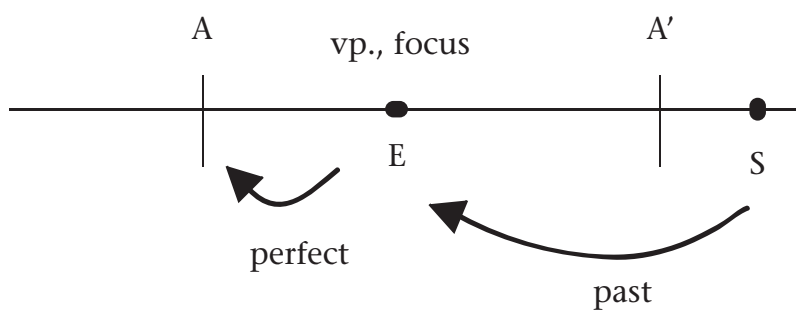

Fig. 2

2 .

The other possibility is that the viewpoint stays in $\mathrm{S}$ and the focus is some reference time $\mathrm{F}$ in the past. The sentence is then in the past, and allerede /already evaluates the time span between $\mathrm{F}$ and $\mathrm{S}$ as being larger than the norm: allerede $i 1979$ var der tale om at nedloegge vaerket/already in 1971 there were plans to close down the factory.

In sum: $\mathrm{S}$ is the moment of speech. If $\mathrm{S}$ is the focus and viewpoint, then allerede/already encodes $A$ as being factual but unexpected relative to $S$ : in this case the sentence is in 
the present tense. If the focus is prior to $S$, then the focus is either an event or a specific time. In the first case $A$ is estimated as being early relative to a viewpoint placed at $\mathrm{E}$, and in the last case the temporal focus is early relative to $S$.

Suppose we have an accomplishment and that the culmination of the process is prior to the moment of speech S, then the adverb allerede/already expresses the speaker's evaluation of how the process went: han har allerede nået toppen/he has already reached the summit, han har allerede malet billedet/he has already painted the picture, etc. The effect of allerede/already is in both cases to stress the unexpectedly quick termination of the processes; in some cases this can give a special force-dynamic effect: han har allerede vundet spillet/he has already won the game; i.e., he was much stronger than his opponent. Note again that in these examples the culminations are represented in the perfect tense, because focus as well as viewpoint are in the present, i.e., at the moment of speech $S$.

If, on the other hand, we have an accomplishment and the moment of speech is prior to the culmination: han er allerede ved at grave haven/he has already started digging the garden, then allerede /already refers to the speaker's evaluation of a circumstance that is external to the process itself. It simply activates an understanding of the early undertaking of the process compared to $\mathrm{S}$.

\section{2. (TEMPORAL MEANING) + FORCE DYNAMICS (CASE II)}

This is a special case of I (see 2.1). We are dealing with a process that from the speaker's point of view has crossed a qualitative boundary. This is not unexpected for the speaker but probably is for the hearer, who might recognize the existence of the very boundary, only later in the process. The speaker therefore conveys crucial information to the hearer. By using the adverb allerede /already, the speaker — besides encoding the factual information - also encodes the hearer's version of the situation, and if the hearer is part of the process, it is often advice that the hearer stop his engagement: $d u$ har allerede sagt for meget/you have already said too much, meaning: this might come as a surprise to you, but according to my version of the situation you should have stopped some time ago. If the hearer is not part of the process it is simply advice that the hearer take his precautions: liget stinker allerede, da det har ligget $i$ fire dage/the corpse smells already since it has been lying there for four days, so it is a good idea to hold your nose. The difference between I (2.1) and II (2.2) is that in I the boundary $A$ is less clear and therefore it can go unnoticed by the hearer. Time is also less profiled. The scale in fig. 1 is rather a dynamic parameter, increasing as a function of time.

Suppose that the focus is prior to the moment of speech, S. In that case, imagined boundary $A^{\prime}$ can be presented as an event in the temporal scope of the already sentence. For instance, vi var allerede traette, da vi fik øje på et troe, der lå tvaers over vejen/we were already tired when we spotted a tree lying across the road. In this case the viewpoint shifted from S, the moment of speech, to the "tiredness space" from which there is focus on event E: to spot a tree. Allerede/already reflects the inappropriateness of being tired in $A$ since one can expect, and indeed one does experience, greater difficulties in $A^{\prime}$, revealed by event E. Cf. fig. 3. 


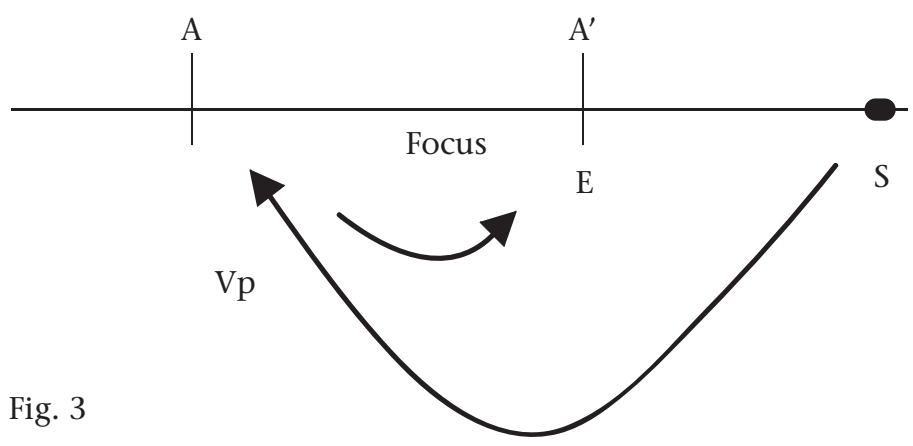

The schema still includes two boundaries and a surprising "distance" between them. The time scale here is equivalent to a scale of exertions.

If there is no event, then at least we need some quantitative contrast (in the case where the focus is prior to moment of speech), as in vi var allerede troette efter en kilometer/we were already tired after one kilometer. Here allerede /already reflects the surprisingly short distance before the state transition, i.e., one would expect the spatial distance to be greater.

Remark that something different happens in the Danish sentence vi var allerede blevet traette, da vi fik øje på et troe, der lå tvaers over vejen/we were already tired when we saw a tree lying across the road. In this case the state transition at $A$ is represented in Danish by the past perfect (var blevet troette). This means that focus and viewpoint are at the $\mathrm{E}$ event (spotting the tree) and that information about the $A$ event is important. However, the meaning of allerede/already is the same as in the previous case. In neither case does it make sense to omit allerede/already because one would then ignore how the two forms of information are related. With the allerede/already sentence we get the factual information of tiredness in a certain time span and by the same token we also know how and why this is relevant for the E event. Furthermore, we see that allerede/already encodes gradation because on a graded scale of 'difficulties', the E event - and what it reveals - ranks higher than the events that caused the tiredness in the first case. This is an indirect result of the fact that allerede/already encodes the unexpectedness of being tired at the moment of $A$.

\subsection{Repetition of AN ACt (CASE III)}

Examples of this include tak, jeg har allerede fäet en kop/I have already got a cup of coffee, thank you, jeg har allerede sagt det mange gange/I have already said it many times, etc. We have identified the schematic meaning of allerede/already to consist of two boundaries in time that represent an actual and a virtual state transition. Moreover, the "distance" between the two boundaries is unexpected for either the speaker or the hearer. How does this schema fit into the repetition of an act? What is the difference between saying "I have got a cup of coffee" and "I have already got a cup of coffee"? The same information concerning the $A$ event - getting coffee — is conveyed, but in the latter case already supplies further information relative to the specific context. One possibility is that according to the speaker a boundary has been reached that is not known to the 
hearer, to whom the boundary might be further away on a scale of coffee drinking. We then have an aspect of the schema presented in 2.2. However, the first boundary $A$ coincides with the ultimate (or penultimate) act. A virtual or actual repetition of the act coincides with the moment of speech and also with the hearer's version of situation $A^{\prime}$. Furthermore, there seems to be some speech-act meaning attached to the use of allerede/ already in these examples. For instance, "I have already got a cup of coffee" means: 'I have got what you offer but I grant that you may ignore it', and "I have said it many times" conveys: 'I have said this before but apparently you haven't noticed it'.

To repeat an act is a dynamic process that may reach a boundary that is not necessarily the same for the speaker and for the hearer. Consider the following: jeg har allerede set filmen fem gange, og jeg skal se den igen i morgen/I have already seen the movie five times and I am going to see it again tomorrow. In this sentence we find that the boundary has not been reached by the speaker, but here allerede/already encodes the possibility of this being the case for the hearer.

\subsection{A fictive SCAle (CASe IV)}

This is a case where allerede/already has no reference to time but still has the schematic meaning shown in fig. 1 . The following are some examples of this: Allerede fuglene tilskriver man misundelse/already the birds are considered envious; allerede venskabet er farligt, aegteskabet endnu mere/already friendship is dangerous, marriage even more so; firbenede hører så godt, at allerede den mindste støj voekker deres opmoerksomhed/quadrupeds hear so well that already the faintest noise arouses their attention.

In the cases considered so far gradation seems to be part of the basic meaning of allerede/ already in the sense that the $A$ boundary can be placed on a graded scale below the $A^{\prime}$ boundary. This graded scale can be time, it can be some conceived force, or it can be the number of times an act is performed. The graded scale can be more or less fictive; in the first example above the speaker seems to imagine the animal kingdom placed on a fictive scale - probably ranked according to intelligence - in the second example it is human relations ordered according to intensity, etc. With the conception of this fictive scale the schematic meaning of the adverb is the same as in the previous cases: a state prevails at a certain point, $A$, on the scale, and the adverb states that this is contrary to normal expectations; normally one does not consider birds as being envious, nor friendships as being dangerous, and so we get the idea that allerede/already evokes a distance between the stated fact and the expected norm; cf. fig. 4.

counter-
factual

factual

Fig. 4

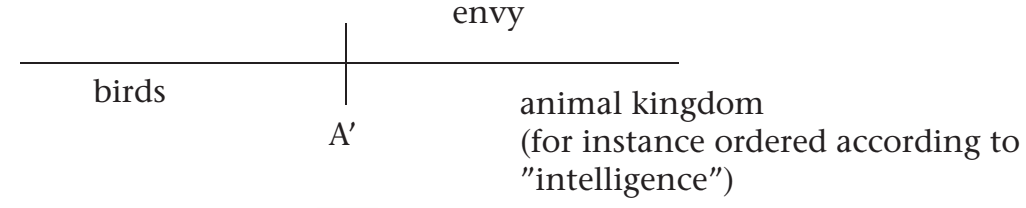

envy

birds

A 


\section{ENDNU/STILL, YET}

\subsection{STADIG/STILL}

The basic schematic form of endnu/still is an inversion of that of allerede/already in the sense that in the prototypical cases, the moment of speech, $\mathrm{S}$, is posterior to the expected state transition, $A^{\prime}$, whereas it is prior to the factual one, $A$; cf. fig. 5.

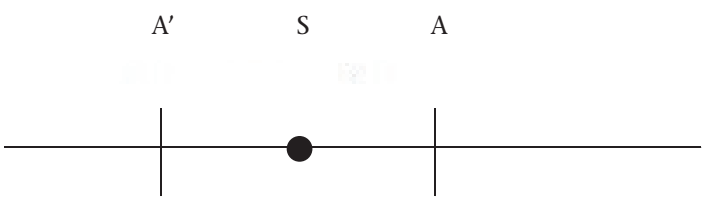

Fig. 5

However, there is another difference, as the state transition in question is one of cessation, whereas in the case of allerede/already it may be one of the onset of a state. Endnu/still evokes a state that is asserted at the moment of speech and is presupposed to have continued up to this moment but was expected to have ceased at a moment prior to the moment of speech: hun sover endnu/she is still sleeping, den er varm endnu/it is still hot, han er endnu for ung til at forstå det/he is still too young to understand, etc.

Since stadig/still encompasses a state that can possibly end, it cannot be used with the perfect aspect, such as for instance *Jens har endnu fodret katten/Jens has still fed the cat. The perfect aspect marks the transition to a state, but it cannot be changed in any way, so there can be no expectation of its cessation. However, endnu/still can be used if there is an additional adverb that acts as a scalar operator, as in Jens har endnu kun fodret katten/Jens has still only fed the cat. In the last case the scalar operator creates some expectation about Jens's further activity.

For almost the same reasons the adverb endnu/still cannot express an accomplishment or an achievement. For instance, the sentence *han faldt endnu ned på bunden af brønden/he still fell down at the bottom of the well is ill-formed, since på bunden/at the bottom implies that the focus is on the completion of the process, whereas endnu/still focuses on the incompletion. This mental conflict can be solved if the process can be interpreted as the last in a series of events: han vandt et parti skak/he won a game of chess is one event and han vandt endnu et parti skak/he won yet another game of chess is one in a series. ${ }^{1}$

Let us look at the cases of simple present. We can consider these sentences as instances of the phenomenon called "window of attention", cf. Talmy (2000: 257-310). There is direct attention to - a window on - a factual state prevailing at the moment of speech. But the adverb endnu/still seems implicitly to evoke a counterfactual space in which the state has ended at a moment prior to the moment of speech. This may be so because this state was expected to end at that moment, but there is yet another possibility. If we consider den er varm endnu/it is still hot, then this utterance can be motivated by a possible interaction with the object, i.e., it is factual that one cannot interact with the object in a period up to and including the moment of speech, but endnu/still evokes the counterfactual scenario in which one could interact with it in this period. A motivation 
for conveying this information might be that the hearer believes in the counterfactual scenario and therefore might act in an inappropriate manner.

To summarize the basic meanings of endnu/still: either the speaker knows the factual state but expected it to have ceased prior to the moment of speech, or the hearer does not know the factual state but believes in a counterfactual version of reality.

Let me now look at the past tense exemplified by han tog studentereksamen, mens han endnu var $17 \mathrm{ar} /$ he got his high school degree while he was still 17 years old. In this case the state — being 17 years old — is the ground for a figure, namely, the event $\mathrm{E}$ - getting the degree. The adverb encodes that the figure is unexpected relative to the ground. A speaker located at the event $\mathrm{E}$ would be surprised to learn that the student was only 17 years old, it would be expected that this state had ended - marked by $A^{\prime}$. The focus of the sentence is clearly the event $\mathrm{E}$, but the viewpoint is located at the moment of speech, so the schematic relation between the various elements is as depicted in fig. 6 .

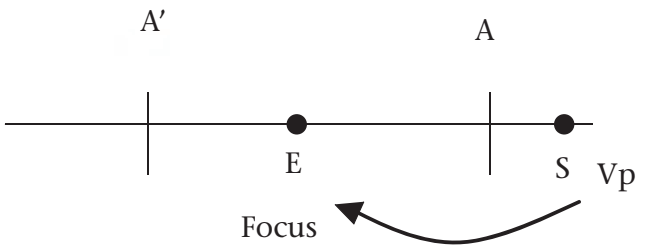

Fig. 6

\subsection{As LATE AS}

The as late as-meaning of the Danish endnu follows the same pattern. An example of this is disse redskaber blev endnu brugt $i$ det 18. årh./these tools were used as late as in the 18th century. Here the sentence explicitly states that the tools were used in the 18th century, but the adverb implicitly refers to an expected counterfactual state where more modern tools were used. Consider also endnu i går så jeg hende/I saw her as late as yesterday, which can be interpreted as "endnu i går var hun i en 'tilstand', hvor hun kunne ses/as late as yesterday she was in a 'state' where she could be seen." The adverb, however, suggests that this 'state' was expected to have ceased $\left(A^{\prime}\right)$ before the event of seeing her (E), so the schematic relation between $A, \mathrm{E}$, and $A^{\prime}$ ' is essentially the same as in fig. 6.

\subsection{ENDNU = 'FURTHER'}

The Danish endnu also means 'further.' Example: hun bliver endnu et par dage/she stays a couple of days more. Here we have a case of a shift in profile. In the present tense the adverb endnu/still will in the standard case profile a state that is prevalent at the moment of speech and in some time interval prior to this moment. But the period posterior to the moment of speech up to the cessation of the state is part of the base meaning of the whole complex. The meaning of endnu that we encounter here is then a shift in profile from the period before to the period after the moment of speech. 
Related to this are examples like der er ti minutter endnu/there are ten minutes left and der er endnu nogle få oebler $i$ kassen/there are still a few apples left in the box. If we instead say: tiden er endnu ikke gået/the time is still not up and der er endnu aebler tilbage i kassen/there are still apples left in the box, then the sentences follow the standard schema. But the elements ti minutter/ten minutes and fä/few in the two first sentences are of course ways of profiling what is left of the state.

Consider also the following examples: hun skriver på bogen endnu/she is still writing the book, this is a state that was expected to have finished. *hun skrev en bog endnu/she still wrote a book, this is an accomplishment which the adverb endnu/still cannot express; cf. above. Hun har skrevet endnu en bog/she has written another book, hun har fået endnu et tretten-tal/she has got another high grade; in these last examples the scope of the adverb is not the accomplishment or the achievement but a countable series of events. ${ }^{2}$ This is also the reason why the verb can be in the perfect tense. The graded scale is not really temporal, it rather comprises the series of discrete events, like a series of numbers. In this case the imagined boundary, $A^{\prime}$, corresponds to the penultimate event in the series (we thought it was finished by then), and the actual boundary, $A$, coincides with the ultimate event. Speech time is posterior to this.

\subsection{Fictive Gradation}

The Danish adverb endnu can exhibit gradation, such as for instance in filmen var endnu sjovere end den foregående/the film was even funnier than the previous one. ${ }^{3}$ We have here an example of gradation, not of time but of the predicate being funny. $A^{\prime}$ is the "amount" of funniness that one can attach to the previous film, which can also be identified with the event of watching the film. The comparative form of the adjective shows that the new film $(A)$ surpasses this boundary and the adverb endnu/still encodes that the extent of the excess is unexpected. Related to this are expressions like det er den voerste ulykke jeg endnu har set/this is the worst accident that I have ever seen. Here we have a graded scale of accidents ranked according to their disastrous effects. Up to the moment of speech, $A^{\prime}$ was the most disastrous event, and endnu/still encodes for the unexpected excess of $A$.

\subsection{Adversative meaning}

The English adverb still has an adversative meaning that the Danish equivalent endnu does not have. This can for instance be illustrated by even if he lost twenty pounds, Harry would still fail the physical. This and other examples are studied in detail in Michaelis (1996). In the standard cases, endnu/still encodes the expected cessation of the state that prevails at the moment of speech. In the adversative cases, there is a similar expectation. $A^{\prime}$ is now an adversity threshold and it is expected that if this threshold is passed, we will not get the outcome presented in the apodosis, in this case the failure of the physical. Still then encodes that the counterfactual state - passing the physical — was expected.

\section{ENDELIG (FINALLY)}

Also in this case the adverb evokes two events, a counterfactual and a factual one. 
The speaker expected the event to happen prior to its actual realization, and it is the speaker's negative evaluation of the distance between the expected and the real moment of realization that is manifested by the adverb. Compared to endnu/still we see that the relation between the expected and the real event is the same, so the only difference is that the speaker's viewpoint is located at the same time as the state transition or later; cf. fig. 7.

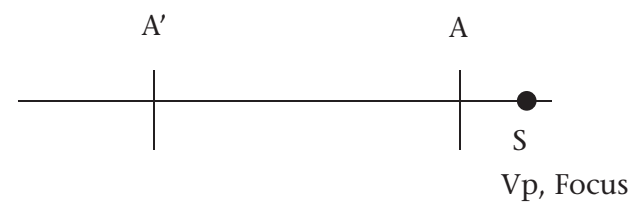

Fig. 7

The dual version of endelig/finally is ikke endnu/not yet in the sense that the difference is determined by the moment of speech, compare fig. 5 with fig. 7.

When the relation between $A^{\prime}, A$ and $\mathrm{S}$ is as depicted in fig. 7, one can either present the event $A$ in the perfect tense and thereby stress that $A$ represents information that is important at the moment of speech - for instance, in doktoren er endelig ankommet/the doctor has finally arrived - or one can use the present tense and thereby profile that the state following $A$ is prevalent at the moment of speech, as in doktoren er her endelig/ the doctor is finally here. In either case it is the present that is in focus, so in either case the focus as well as the viewpoint are located at the moment of speech. Consider a sentence like om en uge er der endelig ferie/in a week the holiday is finally here. Here the use of present tense tells us that viewpoint and focus are at the moment when the real holiday starts - point $A$ in fig. 8. Endelig/finally contrasts this to the moment of speech. When the viewpoint is placed fictively in $A$, the moment of speech now becomes the imaginary start of the holiday, i.e. $\mathrm{S}=A^{\prime}$, cf. Fig. 8 .

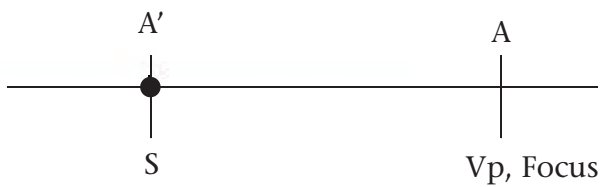

Fig. 8

We see that the moment of speech and the moment $A^{\prime}$ can coincide, but the viewpoint is always located at the moment $A$ or later.

This adverb seems to activate a sense of force dynamics. What motivates its use is the relation between the waiting time between $A^{\prime}$ and $A$ and the degree of emotional involvement in the event $A$. The time span between $A^{\prime}$ and $A$ is normally due to external circumstances that are beyond the speaker's control, whereas the emotional involvement in $A$ is due to the speaker's wishes. Endelig/finally therefore encodes a clash between external reality and the speaker's wish. ${ }^{4}$ Apparently there is no clash in expressions like der er endelig ferie/the holiday has finally arrived, since here reality complies with the speaker's wish. But in this case endelig/finally encodes the existence of 
an imagined beginning of the holiday, $A^{\prime}$, prior to the actual beginning, $A$, and a clash between this time span and the speaker's wish.

In Danish endelig/finally takes on a signification that one does not find in English; it can be exemplified by the sentence $\mathrm{Du}$ må endelig hilse/Be sure to give my regards. In this example there is reference to the future, so the use of endelig/finally may be an instance of the schema in fig. 8. Moreover, the adverb may also mark a clash between the speaker's wish - to give a greeting — and the delay of this event, in correspondence with the force-dynamic pattern mentioned above.

As for allerede/already, there is a difference between it being an achievement or an accomplishment that is in the scope of endelig/finally. In an achievement only the end point of a process is profiled. Endelig/finally will therefore mark a distinction between the expected and the factual moment of time at which the process finished. It will therefore comment on the internal dynamic development of the process; cf. de nåede endelig toppen/they finally reached the top, where the adverb conveys the meaning that it has been more difficult than expected. An accomplishment, on the other hand, profiles a specific interval. The adverb will therefore mark a distinction between the expected and the factual period of time in which the process unfolded. Consequently, the meaning is that the whole process was delayed relative to what was expected.

\section{SNART/SOON}

For this adverb there are two main schematic relations between events. In one version the moment of speech coincides more or less with the occurrence of an event expected by the speaker, who assures that the realization is not far off: jeg er snart foerdig/I will soon be finished, jeg skal snart drikke giften/I will soon drink the poison. Viewpoint and focus are in the future event and snart/soon marks the span between the moment of speech and the fictive viewpoint.

The other meaning of snart/soon is expressed in the sentence soon afterwards, a direct charge of plagiarism was made. The moment of speech here is later than the event in focus, and soon marks that the time span between the focused event and an earlier causal event is less than could normally be expected.

\section{CONCLUSION}

One can expect language to offer constructions by means of which the language user can express the relation between the moment when an event happens and the moment at which it was expected to happen. There are, then, only two possibilities: that the actual moment is prior to the expected one, or vice versa. In the first case only the situations in which the moment of speech is posterior to the event are of interest, and they are encoded by allerede/already. In the last case we have two possibilities: the moment of speech is posterior to the expected moment of time but prior to the factual one. This situation is essentially encoded by stadig/still or endnu/yet. Or the moment of speech can be posterior to the event, in which case the adverb endelig/finally can be used. The adverbs allerede/already, endnu/still, and endelig/finally therefore fit into a 
common framework: the moment of speech in its relation to an event and its expected realization. Moreover, the non-temporal meanings of the adverbs can be considered as motivated by the general schema underlying their temporal frame. In other words, the non-temporal sense has the same schematic meaning as the temporal one, but is transferred to another frame.

\section{REFERENCES}

Fauconnier, Gilles (1997), Mappings in Thought and Language, Cambridge, New York: Cambridge University Press.

Michaelis, Laura A. (1996), "Cross-World Continuity and the Polysemy of Adverbial Still", in: Fauconnier, Gilles, Eve Sweetser (eds.) (1996), Spaces, Worlds and Grammar, Chicago: University of Chicago Press, pp. 179-226.

Talmy, Leonard (2000), Toward a Cognitive Semantics, Cambridge/Mass.: MIT Press.

\section{NOTES}

1 The same interpretation could in principle be applied to the sentence: *han faldt endnu ned på bunden af brønden/he still fell down at the bottom of the well, but here it seems less likely.

2 Compare *han nåede endnu toppen with han nåede toppen endnu en gang/he reached the top once more. In the first example, endnu expresses an achievement which is infelicitous. In the last case it expresses a series of achievements which makes sense.

3 Here we find another interesting phenomenon that has nothing to do with adverbs. An effect can become a predicate for the cause; for instance, in a loud man, it is the man that is the cause of the loudness, but the effect is then used as a predicate of the man. In the example, the film is funny because it has an effect on the viewer, who has fun watching it, and this effect then becomes a predicate of the film.

4 Talmy makes the same observation (Talmy 2000: 449), where he comments on the sentence the lizard finally moved. 